УДК 655.59:94(477)

๑ М. Т. Андрійчук, к.н. із соц. комунікацій, НТУУ «КПІ”, Київ, Україна

\title{
ВИДАВНИЧА СПРАВА У ПІДРАДЯНСЬКІЙ УКРАЇНІ У МІЖВОЄННИЙ ПЕРІОД
}

У статті розглянуто питання організації видавничої справи

в підрадянській Україні у міжвоєнний період - після

встановлення на цих землях влади російських більшовиків

та виникнення маріонеткового утворення УСРР. Розглянуто

вплив політики українізації на розвиток українськомовного

книговидання та роль, яку відводили більшовики видавничій справі у реалізації цієї політики.

Ключові слова: видавнича справа; видавництва; видання; українізація; українське книговидання.

\section{Постановка проблеми}

Важливою складовою духовного життя Великої України у міжвоєнний період (1918-1939) була видавнича справа. Вона отримала поштовх до розвитку в роки національно-визвольних змагань (1917-1921) і особливо активно розвивалась в УСРР у період українізації (1923-1932), навіть попри встановлену московським більшовицьким режимом державно-партійну цензуру та поступове запровадження суворої централізації українського книговидання. Але у фаховій літературі різні аспекти розвитку української видавничої справи підрадянської України у зазначений період не знайшли належного відображення.

\section{Аналіз попередніх досліджень}

Окремі питання розвитку українського книговидання в УСРР у 1920-1930-х рр. (статистика друку, типологічний і тематичний аналіз) у своїх працях ви-

\footnotetext{
(c) $2015 \mathrm{p}$.
}

світлювали ще дослідники першої половини XX ст. як власне 3 підрадянських теренів (В. Ігнатієнко, А. Козаченко, Ю. Меженко, М. Годкевич, Б. Фідельман), так і з української еміграції (Ю. Тищенко, С. Сірополко, О. Лотоцький, П. Зленко, В. Дорошенко).

У 50-80-х рр. XX ст. проблему розвитку видавничої справи у підрадянській Україні у міжвоєнний період порушували В. Білозуб, А. Молодчиков, Т. Скрипник, Р. Машталер, Ж. Ковба, М. Феллер, М. Гуменюк та інші. Зрозуміло, що праці цих авторів мали певні ідеологічні нашарування та свідомо уникали висвітлення деяких аспектів тогочасного розвитку видавничої справи.

У добу незалежності України питання розвитку видавничої справи, тематико-типологічної характеристики видавничої продукції, статистики друку цього періоду порушували Г. Ковальчук, М. Тимошик, Я. Ісаєвич, 
М. Низовий та низка інших авторів. Однак, ці праці носили оглядовий характер. Т. Ківшар у своїй монографії «Український книжковий рух як історичне явище (1917-1923 рр.)» торкнулася лише питань розвитку української видавничої справи початку 20-х рр. XX століття. Сучасний дослідник О. Яковлєв розглянув культурологічні виміри українського книговидання у 20-ті pp. XX століття.

Тому актуальною $€$ поява праць, які б комплексно розглядали ретроспективи розвитку української видавничої справи на Наддніпрянщині та охоплювали б увесь міжвоєнний період.

\section{Мета роботи}

Висвітлення питання розвитку української видавничої справи у підрадянській Україні у перші два десятиліття після встановлення більшовицького режиму.

\section{Результати проведених досліджень}

У роки І Світової війни (1914-1918) українське книговидання переживало глибоку кризу. Однак, з початком української національної революції у 1917 р. та в наступні її роки, незважаючи на важкі реалії воєнного часу, ситуація змінилася на краще. Так, у 1917 р. у Великій Україні побачили світ 1373 назви видань. 3 них 747 вийшли українською мовою, що становило 54,4 \% від загальної кількості усіх видань. Загальний тираж усіх виданих книг становив 12 млн. 448 тис. примірників [1, С. 9]. У 1918 р. на Наддніпрянщині уже вийшло 1525 назв видань, з яких 1084 були українською мовою, 386 російською і 56 мовами інших меншин [2, С. 481]. Розвитку українського книговидання в цю добу сприяли законодавчі акти про книгу і пресу Центральної Ради, Гетьманського уряду та Директорії УНР. Саме тоді була фактично сформована система національної книговидавничої справи та періодики.

У цей час були створені нові як державні, так і кооперативні видавництва. Помітно активізувалась діяльність приватних видавництв щодо випуску українськомовної друкованої продукції. Вирізнялися видавничою активністю й українські університети (Київський та Кам'янецьПодільський) і наукові установи (Академія наук). Серед видавництв досить помітними були «Час», «Вік», «Дзвін», «Криниця», Український Кооперативний Видавничий Союз, Всеукраїнське видавництво вчителів, «Дніпросоюз», «Сяйво», «Книгоспілка» і «Рух», видавництва $€$. Вирового, М. Кащенка, М. Загірної [3, C. 408-409].

Потяг українського народу до освіти та писемності сприяв збільшенню випуску навчальнопедагогічної книжки. Помітну роль у становленні українського навчально-педагогічного книговидання відіграв міністр освіти УНР І. Огієнко. Уніфікації українського книговидання сприяло поширення в освітянських закладах «Найголовніших правил українського правопису». Директорією УНР 24 січня 1919 р. був прийнятий «Закон про утворення Головної Книжної палати в м. Києві» - першої спе- 
ціальної державної бібліографічної установи для реєстрації всієї української друкованої продукції [4, С. 41]. Відбулися становлення та розвиток українського книгознавства, організація державної бібліографічної служби видавничо-книготорговельної бібліографії. Цьому сприяв і розвиток книгознавчої преси (зокрема, вихід журналу «Книгар»).

Бібліотечний рух в Україні у той час набирає рис масовості. Завдяки громадським ентузіастам та державним органам були створені прилюдні та просвітянські книгозбірні, а також Національна бібліотека Української держави, Всенародна бібліотека України. За сприяння головного отамана С. Петлюри українська книжка поширюється серед вояків. Також була утворена мережа книгозбірень Армії УНP.

Разом 3 тим Національновизвольна українська революція 1917-1921 рр. завершилась поразкою, більша частина українських земель опинилась під владою більшовицького режиму. Це негативно позначилось на українськомовному книговиданні, яке сприймалося радянською владою як ідеологічно вороже явище. Відбулися націоналізація та реквізиція видавництв, друкарень, бібліотек, запровадження більшовицької цензури. Для керівництва видавничою справою в Україні були створені спеціальні радянські державні органи. Зокрема, з метою контролю над видавцями радянським урядом у 1922 р. було створено Головне управління 3 питань літератури і видавництв
(Головліт), що виконувало функції цензурної установи [5, С. 9]. Відбувається нищення української книжки. Натомість в Україні поширюється російська радянська література й преса. Фактично відбувається зросійщення України.

Динаміку зменшення кількості українськомовної друкованої продукції демонструє статистика. Зокрема, у 1917 р. вийшло 747 назв українськомовних видань, у 1918 р. - 1084 назви. Однак, вже у 1919 р. вийшло лише 665 українськомовних назв видань і 726 російськомовних; у 1920 р. - 457 українськомовних і 369 російськомовних; у 1921 р. - 214 українськомовних і 448 російськомовних; у 1922 р. - 385 українськомовних і 927 російськомовних назв [6, С. 110]. Тенденція до збільшення кількості російськомовної книговидавничої продукції продовжувалась навіть у перші роки проведення політики українізації. Зокрема, у 1923/1924 операційному році вийшло 385 українськомовних назв видань і 927 російськомовних; у 1924/1925 році - 1813 українськомовних і 2535 російськомовних; у 1925/1926 році 2162 українськомовних назв і 2365 російськомовних. Лише у 1931 р. українськомовна книжкова продукція за назвами стала переважати російськомовну 6218 назв українських видань проти 2014 назв російськомовних. Однак, на книготорговельний ринок УСРР також продовжували поступати російськомовні видання з РСФРР та інших радянських республік [6, С. 110]. Середній тираж видань в УСРР у 
1930 р. складав 15,4 тис. примірників [7, С. 3]. Російськомовна друкована продукція домінувала й на ринку періодики. Зокрема, станом на 1 квітня 1924 р. серед 68 газет, що виходили в УСРР, усього лише 22 газети були українськомовними. Станом на 1 лютого 1925 р. $з 74$ газет лише 34 були українськомовними. Змістовне наповнення цієї преси носило переважно агітаційне забарвлення, які пропагували комуністичну ідеологію та радянські цінності [8, С. 19].

Провідне місце в українському книговиданні в ці роки займало Всеукраїнське видавництво (Всевидав) при ВУЦВК, що утворилось у травні 1919 р. на базі багатьох видавництв. У січні 1920 р. воно отримало назву Всеукраїнське державне видавництво (Всеукрдержвидав) й було підпорядковано Президії ВУЦВК, а з травня 1921 р. Наркомату освіти УСРР. 18 серпня 1920 р. урядом УСРР було затверджене положення про всеукраїнське державне видавництво, згідно з яким Всеукрвидаву, як центральному видавничому органу ВУЦВК, було надано право об'єднання, а також регулювання видавничої діяльності всіх організацій радянської України, переважного використання підприємств поліграфічного виробництва і розподілу всього паперу. У грудні 1921 р. Всеукрвидав у зв'язку зі складною економічною ситуацією затверджує розпорядження, згідно з яким заборонялося виділяти папір всім установам і закладам, окрім редакцій ряду газет і видавництв, що випускали партійну літературу - тобто листівки, агітаційні брошури тощо. Всі наявні запаси паперу в Україні вилучались державою.

Книготоргівля як така зникла, коли усіх книгарів-одноосібників та кооператорів у 1920 р. було підпорядковано Всеукрдержвидаву. Книжку заборонили продавати як буржуазну розкіш, а увесь книжковий обіг в Україні став «чорним» і букіністичним. У цей час особливо популярною стала навчальна література. Тих мізерних тиражів українських підручників, що видавали радянські видавництва, не вистачало, тому на букіністичному ринку продовжували обертатись підручники та посібники, видані у кооперативах та приватних видавництвах. Формою оплати за книги в роки воєнного комунізму були продукти харчування. Гонорари авторам книг також виплачувались продуктами або частиною тиражу. Все це привело до занепаду видавничої галузі.

У серпні 1922 р. Всеукрдержвидав було перейменовано на Державне видавництво України (ДВУ). У цей час на базі приватних були створені інші державні, партійні, воєнні видавництва та видавництва громадських організацій. Так, у 1922 р. в Харкові були засновані видавництва «Пролетар» і «Молодий робітник». В їх книжковому репертуарі переважала агітаційнопропагандистська література, популярні масові книги. Виходили також твори художньої літератури, наукова і літературна періодика, щоденна преса.

Певне піднесення книговидавничої галузі відбулося після 
запровадження радянським урядом нової економічної політики (НЕП). Цьому сприяли не тільки економічні перетворення, але й перетворення в галузі культури. Повсюдно проводилась боротьба 3 неграмотністю, замість ліквідованих відділень Товариства «Просвіта» створювались хати-читальні, сільбуди, школи. Книга знову повертається на ринок. Починають діяти кооперативні видавництва («Час», «Рух»), відновлює діяльність видавництво «Книгоспілка» та інші. Загальне число видавництв в 1922 р. становило 172, а в 1923 р. - 140 [9, С. 170].

У квітні 1923 р. ХІІ з'їзд РКП (б) проголошує політику коренізації, яка в Україні стала відома як політика українізації. Важлива роль у втіленні політики українізації відводилась радянським керівництвом видавничій справі. Зокрема, в одній із Постанов Політбюро ЦК КП(б)У «Про становище друку на УКраїні» від 25 серпня 1926 р. прямо зазначалось: «Українська книга, журнал, газета закликані розвитком культурно-національного життя, під проводом пролетаріату, в руках Комуністичної партії, відіграти велике значення в справі будування соціалізму серед широких багатомільйонних мас українських робітників і селян» [10, С. 159].

Доба українізації стала періодом відродження української культури. У Харкові створюються перші українські радянські письменницькі організації: «Плуг» (1922-1932) - спілка селянських письменників, «Гарт» (1923-1925) - спілка пролетарських письменників. Окрім цього, існували й групи «непролетарських письменників». У 1924 р. в Києві утворюється літературна група «Ланка», яка згодом була перейменована на МАРC - Майстерня Революційного Слова. У 1925 р. організація «Гарт» розпадається, а натомість утворюється нова письменницька організація Вільна академія пролетарської літератури (ВАПЛІТЕ) [11, С. 277-278]. Літературний рух сприяв розширенню тематики українських видань.

у 1924-1928 рр. розвиток видавничої справи в УСРР відбувався при суттєвих змінах у соціально-економічному житті. Поступово згорталася політика НЕПу, натомість економіка все більше підпадала під адміністративні важелі управління. Незважаючи на вищезгадані фактори, а також паперову кризу, обмеження кредитів, перебудову видавництв у зв'язку з їх спеціалізацією, що досить помітно стримувало їх розвиток, обсяг виробництва книжкової продукції в УСРР зростав. У 1928 р. загальний обсяг книжкової продукції підрадянської України складав 5413 назв і майже досяг рівня обсягу такої продукції на Наддніпрянщині у 1913 р. (5579 назв). 3 року в рік зростала кількість назв українською мовою. Так, якщо у 1924-1925 рр. ця кількість становила $40 \%$, то у 1927-1928 рр. 53,9 \% від загального обсягу. Випуск російськомовних видань відповідно скорочувався: у 1924-1925 рр. - 56,2 \%, а у 1927-1928 pp. - 41,2 \%. На етапі згортання більшовицьким режимом політики українізації у 
1933 р. українськомовна видавнича продукція значно переважала російськомовну та видання мовами нацменшин - 3472 з 5012 назв [12, С. 977]. 3 російськомовних видань значна частина (насамперед, політичних) була розрахована на ринок СРСР. Особливо це стосувалось видавництва «Пролетарій». Водночас слід звернути увагу, що хоч випуск українськомовної книги з таких видів літератури, як художня, технічна, сільськогосподарська зростав, однак українськомовних книг з математики, фізики, хімії, медицини тощо виходило недостатньо, що стримувало процеси українізації науки [13, С. 56-57].

У книговиданні переважала державна форма власності у вигляді урядових, наукових, партійних, професійних видавництв (випускали 90-95 \% від усієї книжкової продукції УСРР). На найбільше 3 цих видавництв - Державне видавництво України (ДВУ) припадало 29-35\%. Незважаючи на залежність, частка приватних видавництв також зросла від 4 \% у 1924 р. до 10 \% у 1927 році. Однак, 3 часом держава усуває приватне книговидання. У першу чергу це стосується дитячої літератури, випуск якої до того зосереджувався головним чином у приватних видавництвах, а пізніше видання дитячої літератури перейшло до державних видавництв. Це все відбувалося в руслі тодішньої офіційної політики радянської держави. Книга радянською владою розглядалась як один із головних засобів в ідеологічній боротьбі. Саме тому робились кроки що- до централізації видавничої галузі та посилення контролю за нею. 3 цією метою на одній із всесоюзних книготорговельних нарад у 1929 р. лунали заклики до подальшої спеціалізації (типізації) видавництв, поширення видання масової літератури, зменшення ціни на книжку, а також посилення регулюючого впливу Комітету у справах друку в книговиданні та книгопоширенні $[14$, С. 3].

у 1928-1929 рр. в основному завершились процеси спеціалізації видавництв, що й підтверджується даними стосовно тематики видавничого репертуару. Зокрема, навчальна книга становила переважну більшість книжкової продукції у ДВУ $75 \%$ та видавництві «Пролетарий» - 52 \% видань. 3 випуску масової книжки перше місце посідало видавництво «Радянський селянин» - 95,8 \% всієї книжкової продукції, «Український Робітник» - 90 \%, «Книгоспілка» - 35 \%, «Пролетарий» - 24 \%. Художню літературу видавало переважно ДВУ - 8 \% від всієї своєї продукції, «Книгоспілка» - 33 \%, «Пролетарий» - 8,5 \%. Українська книжка у відбитках становила - $84 \%$, російська $12 \%$, інша (тобто книга більшості етнічних меншин) -4 \%. 3 видавництв основної групи, російська книжкова продукція переважала у «Науковій думці» - 64 \%. У видавництві «Пролетарий» російські видання переважали у назвах та тиражах, але у відбитках більша частина друкованої продукції була за мовою українською. Такі видавництва як «Радянський Се- 
лянини» та «Рух» видавали виключно українськомовну книгу [15, C. 4].

Як уже згадувалось, провідні позиції серед видавництв України займало ДВУ, що містилось у Харкові і мало мережу губернських відділень та представництва в Москві, Ленінграді, інших містах СРСР. ДВУ випускало суспільно-політичну, навчальну, наукову, художню, технічну літературу, а також регулювало видавничу діяльність різних установ, товариств тощо. У ньому виходили твори Т. Шевченка, Марка Вовчка, І. Франка, М. Коцюбинського, Лесі Українки. В. Винниченка, А. Тесленка, В. Стефаника, М. Хвильового, Г. Косинки, Остапа Вишні, В. Поліщука, В. Сосюри, О. Досвітнього, А. Головка та ін. У цьому ж видавництві виходили такі журнали й альманахи, як «Гарт», «Плуг», «Життя і революція», «Критика», «Червоний шлях» та інші. У грудні 1930 р. ДВУ було перейменовано в Державне видавниче об'єднання України (ДВОУ). Воно діяло в Харкові при Наркоматі просвіти УРСР. Це об'єднання включало такі видавництва, як «Пролетар», що випускало соціальноекономічну і політичну літературу, «Молодий більшовик» - масову і політичну літературу, «Література і мистецтво» - художню і мистецтвознавчу літературу та критику, «Радянська школа» - навчальну літературу, «На варті» - військову літературу, «Український робітник» масову професійну літературу i літературу з охорони праці, «Мистецтво» - плакати і музичну літературу. Медичну літера- туру випускав «Держмедвидав», технічну - «Державне технічне видавництво», а сільськогосподарську - «Державне сільськогосподарське видавництво». ДВОУ припинило своє існування у березні 1934 року.

Серед інших видавництв варто відзначити Книгоспілку Київське націоналізоване видавництво, яке підпорядковувалося спочатку Вукоопспілці, а потім Всевидаву. Книгоспілка, на відміну від ДВУ, де окрім українськомовних виходило й багато російськомовних книг, видавало переважно українськомовні книги. Випуск книг російською та іншими мовами становив всього 10 \% від загального числа. У Книгоспілці виходили підручники, науково-методична, дитяча література, книги з мистецтва, довідкові видання, література для юнацтва.

У 1925 р в Харкові було засновано видавництво «Радянський селянин», яке випускало сільськогосподарську літературу і складало серйозну конкуренцію Книгоспілці. Величезна видавнича діяльність проводилась і Українським науковим інститутом книгознавства.

У 1920-х рр. мали змогу працювати деякі приватні видавництва. Зокрема, видавництво «Рух», що діяло в Харкові 3 1925 р. і випускало книги виключно українською мовою. Це були переважно твори української класики, «Театральна бібліотека» та ін. Твори неокласиків видавались у видавництві «Слово», яке діяло в Києві 3 1923 року. У 1926 р. були засновані і якийсь час продовжували свою діяльність приватні ви- 
давництва «Сяйво» і «Культура».

У Державному видавництві національних меншостей УРСР (Держнацменвидав УРСР), яке було створено в 1931 р. в Харкові на базі реорганізованої Всеукраїнської філії Центрального видавництва народів СРСР при ЦВК СРСР, до липня 1941 р. видавалась література національних меншин України.

Станом на 1931 р. книжкова продукція УСРР розподілялась за тематикою й призначенням наступним чином: соціальноекономічна становила 33,7 \%, точні науки й техніка $-28,3 \%$, художня література - 9,3\%, мовознавство - 21,7 \%, медицина $-1,9 \%$, література інших тематичних груп - 5,1\% [13, С. 977]. Випуском технічної книги в радянській Україні займались 2 видавництва, що були в системі ДВОУ - Держтехвидав та «Український робітник». За період 3 жовтня 1930 до жовтня 1931 р. вони видали 30 назв технічної книги обсягом 3755 аркушів [16, С. 8]. Як бачимо, технічна книга видавалась у недостатніх кількостях. На цей факт змушений був звернути увагу ЦК ВКП (б) у своїй постанові від 5 серпня 1931 р., де було відзначено незадовільний стан з випуском технічної та наукової книги. Для виправлення ситуації було вирішено для Держтехвидаву виділити не менше $1 / 4$ паперових та поліграфічних запасів, що є у розпорядженні ОГІЗУ [16, С. 7].

Особлива увага більшовицьким керівництвом приділялась випуску масової книжки, яка мала виконувати агітаційно- пропагандистську функцію. Як зазначалося в одній зі статей у журналі «Радянський книгар» (1929, № 1): «В умовах України масова книжка мусить також бути одним із головних чинників, що сприяє втягненню широких кіл трудящих до національнокультурного будівництва...» [17, C. 6].

Низка видавництв значно вирізнялися своєю потужністю серед інших підприємств галузі, про що свідчать статистичні дані. Зокрема, більшість книжкової продукції УСРР (близько $90 \%$ у у 1928/1929 операційному році випускали видавництва так званої основної групи (ДВУ, «Книгоспілка», «Пролетарий», «Український Робітник», «Радянський Селянин», Юридичне видавництво, «Наукова Думка», Центрвидав, «Культура», «Культур-Ліга», «Рух» та ін.) [15, С. 3].

Цей факт підтверджується й наведеними нижче даними таблиці.

Книжкова продукція перерахованих 16 видавництв у 1928/1929 операційному році, за даними Книжкової палати, становила 80 \% всієї книжкової продукції України за назвами, 93,3 \% - за тиражами, 90,8 \% за відбитками [18, С. 9]. Частка приватних видавництв доволі невисока.

Загальний тираж книжкової продукції у 1928/1929 операційному році становив $9 \mathrm{Mлн.}$ 420 тис. примірників [19, С. 4]. Помітна в цьому році подальша тенденція до українізації книги. Зокрема, книжкова продукція українською мовою склала за назвами 69,4 \% на відміну від $53,2 \%$ у 1927/ 1928 році, за 
Статистичні дані випуску книжкової продукції УСРР у 1928/1929 операційному році

\begin{tabular}{|c|c|c|c|}
\hline Видавництва & Назва & Тираж & Відбитки \\
\hline ДВУ & 1140 & 17 млн 473 тис. & 157 млн 728 тис. \\
\hline «Книгоспілка» & 392 & 3 млн 677 тис. & 21 млн 617 тис. \\
\hline «Пролетарій» & 339 & 4 млн & 22 млн 843 тис. \\
\hline «Український Робітник» & 242 & 2 млн 801 тис. & 12 млн 343 тис. \\
\hline «Радянський Селянин» & 375 & 5 млн 139 тис. & 12 млн 3 тис. \\
\hline Юридичне видавництво & 97 & 650 тис. & 3 млн 333 тис. \\
\hline «Наукова Думка» & 137 & 1 млн 356 тис. & 2 млн 579 тис. \\
\hline Центрвидав & 231 & 1 млн 286 тис. & 7 млн 183 тис. \\
\hline «Культура» & 213 & 4 млн 63 тис. & 6 млн 716 тис. \\
\hline «Pyx» & 86 & 470 тис. & 4 млн 12 тис. \\
\hline «Культур-Ліга» & 53 & 243 тис. & 2 млн 547 тис. \\
\hline ДВ. АМСРР & 48 & 121 тис. & 713 тис. \\
\hline «Плужанин» & 35 & 208 тис. & 323 тис. \\
\hline $\begin{array}{c}\text { Разом державні, } \\
\text { кооперативні та } \\
\text { громадські видавництва }\end{array}$ & 3388 & 41 млн 487 тис. & 253 млн 940 тис. \\
\hline Уніздат & 40 & 213 тис. & 1 млн 892 тис. \\
\hline «Чac» & 26 & 117 тис. & 1 млн 140 тис. \\
\hline «Сяйво» & 44 & 278 тис. & 1 млн 261 тис. \\
\hline $\begin{array}{c}\text { Разом приватні } \\
\text { видавництва }\end{array}$ & 110 & 608 тис. & 4 млн 293 тис. \\
\hline Всього & 3498 & 42 млн 95 тис. & 258 млн 233 тис. \\
\hline
\end{tabular}

друкованими аркушами 67,7 \% на відміну від 57,1 \%, за тиражами $77 \%$ на відміну від 65,3 \%. Російська книга домінувала лише серед технічної та медичної літератури. Зростала й кількість видань національних меншин. Вийшло 466 назв таких видань проти 261 у 1927/1928 році (збільшення на 78,8 \%), за друкованими аркушами - 2 млн. 370 тис. проти 1 млн. 41 тис. (збільшення на 127,7 \%), за тиражем - 2 млн 69 тис. прим. проти 957 тис. (збільшення на $116,2 \%)$ [19, С. 6].

Наприкінці 1920-х-на початку 1930-х рр. відбувся наступ центрального московського уряду на здобутки українізації.
Розпочались зворотні процеси деукраїнізації. Головного удару було завдано по тих керівниках республіки, які найбільше сприяли політиці українізації. Перш за все, це нарком освіти УРСР у 1924-1926 рр. О. Шумський, який відповідав за політику українізації. Його зняли з посади на лютнево-березневому пленумі 1927 р. ЦК КП(б)У за захист «націоналістичного ухилу» Миколи Хвильового та штучне прискорення процесів українізації та вислали за межі республіки. Однак, остаточний крах політики українізації ознаменувало у липні 1933 р. самогубство наркома освіти УРСР М. Скрипника. 
Було сфабриковано і ряд справ проти української інтелігенції. Так, у 1930 р. розпочався процес проти Спілки Визволення України (провідних діячів української науки), Української військової організації (УВО), «Блоку українських націоналістичних партій». Сотні діячів культури були заарештовані і знищені або репресовані. Паралельно в 1933 р. Сталін оголосив головною небезпекою український націоналізм [20, C. 519]. Тому зменшувалась кількість українських шкіл, скорочувався відсоток українських учителів та науковців, закривались українські театри та заборонялось ставити п'єси українською мовою, зменшувався випуск українськомовної видавничої продукції. Якщо в 1931 р. у Великій Україні виходило 90 \% газет і $85 \%$ журналів українською мовою, то у 1940 р. ї число скоротилось - газет до 70 \%, а журналів до 45 \% [20, С. 520]. у 1938 р. у всіх школа було запроваджено обов'язкове вивчення російської мови. Були зроблені кроки до максимального наближення українських алфавіту і граматики до російських алфавіту і граматики. Це позначилось і на виданні українських книжок. Так, вже у 1934 р. $з 4711$ назв книг всіма мовами 2750 були українською мовою. У 1938 р. загальна кількість назв книг становила 4174, з них українською мовою 2159, а вже в 1939 році відповідно 4369 назв і з них лише 1895 українською мовою [13, C. 977].

\section{Висновки}

Отже, як бачимо, у другій половині 1930-х рр. кількість українськомовної видавничої продукції з року в рік зменшувалась. Це було наслідком згортання політики українізації, що спочатку задумувалась як інструмент радянської влади для формування з українського народу лояльних до більшовицького режиму громадян та ідеологічного виховання прихильників комуністичних ідей. Однак, згодом, коли політика українізації продемонструвала позитивні зрушення у багатьох сферах національно-культурного життя (у тому числі і у видавничій справі) проросійське радянсько-комуністичне керівництво на чолі зі Сталіним угледіло загрозу зростання українського націоналізму, що в майбутньому могло становити загрозу існуванню радянській імперії. Тому політика українізації була згорнута, що безпосередньо негативно позначилось на стані української видавничої справи в УСРP.

\section{Список використаної літератури}

1. Фідельман Б. До підсумків видавничої роботи на Україні за 15 років / Б. Фідельман // Рад. книгар. - 1932. - № 31. - С. 9-12.

2. Сірополко С. Історія освіти в Україні / С. Сірополко. - К. : Наук. думка, 2001. - 912 c.

3. Ісаєвич Я. Д. Українське книговидання : витоки, розвиток, проблеми / Я. Д. Ісаєвич. - Львів : Інститут українознавства ім. І. Крип'якевича НАН України, 2002. -520 с.

\section{2}


4. Низовий М. Українська статистика друку : основні етапи становлення та розвитку / М. Низовий. - К. : Кн. палата України, 2002. - 96 с.

5. Яковлев О. В. Історико-культурологічні виміри книжкового друку в Україні у 20-ті роки XX століття : автореф. дис. на здобуття наук. ступеня канд. іст. наук. 26.00.01 - теорія та історія культури / О. В. Яковлев. - К., 2010. - $16 \mathrm{c}$.

6. Лотоцький О. Українське друковане слово / О. Лотоцький // Антонович Д., Лотоцький О. Українська книга // Українська культура : лекції за ред. Д. Антоновича / упор. С. В. Ульяновська ; вст. ст. І. М. Дзюба ; перед. слово М. Антоновича ; додатки С. В. Ульяновської, В. І. Ульяновського. К. : Либідь, 1993. - 592 с. («Пам'ятки історичної думки України»). С. $98-111$.

7. Годкевич М. На порозі п'ятнадцятого / М. Годкевич // Рад. книгар. 1931. - № 31. - С. 3-7.

8. О. Б. Видавнича справа на Україні / О.Б. // Тризуб. - 1926. - № 45 (5 вересня). - С. 16-20.

9. Ківшар Т. Український книжковий рух як історичне явище (19171925 рр.) : монографія / Т. Ківшар. - К. : Логос. 1996. - 334 с.

10. О состоянии печати на Украине (25 августа 1926 г.) : Из постановления Политбюро ЦК КП(б)У // Книга и книжное дело в Украинской ССР : сб. докум. и материалов, 1917-1941 / [Сост. Л. И. Гольденберг (рук. работы) и др.]. - К. : Наук. думка, 1985. - Т. 1. - С. 159-164.

11. Історія України / відп. ред. Ю. Сливка ; керівник авт. кол. Ю. Зайцев. - Вид. 3-тє, перероб. і доп. - Львів : Світ, 2002. - 520 с.

12. Дорошенко В. Видавництва / В. Дорошенко, П. Зленко // Видавництва і преса // Енциклопедія українознавства. Загальна частина. Перевидання в Україні. - К. : НАН України, Ін-т української археографії, 1993. T. 3. - С. 973-981.

13. Яковлев О. Основні тенденції розвитку книговидання в Україні у 1924-1928 рр. / О. В. Яковлев // Книга в соціокультурному просторі (досвід книговидання XIX-XX ст. і сучасні проблеми) : доповіді і повідомлення Міжнародної наукової конференції, 3-5 травня 1995 р. - Львів, 1995. C. $56-57$.

14. Агуф М. Книга - гвинтівка на культурному фронті (Підсумки всесоюзної та всеукраїнської книготорговельних нарад) / М. Агуф // Рад. книгар. - 1929. - № 1. - С. 2-6.

15. Пічугин М. Українські видавництва в $1928 / 29$ році (За попередніми даними) / М. Пічугин // Рад. книгар. - 1930. - № 3. - С. 3-4.

16. Штоке Г. Технічна книжка до XIV річниці Жовтня / Г. Штоке // Рад. книгар. - 1931. - № 31. - С. 7-9.

17. А. Л. Асортимент масової української книжки / А. Л. // Рад. книгар. 1929. - № 1. - С. 6-8.

18. Фідельман Б. Українські книжкові видавництва в 1928/29 році / Б. Фідельман // Рад. книгар. - 1930. - № $13-14$. - С. 8-11.

19. Александров С. Перші підсумки книжкової продукції УСРР 1928/29 року / С. Александров // Рад. книгар. - 1930. - № 1. - С. 4-6.

20. Субтельний О. Україна : історія / пер. з англ. Ю. І. Шевчука ; вст. ст. С. В. Кульчицького. - 3-тє вид., перероб. і доп. - К. : Либідь, 1993. $720 \mathrm{c}$. 


\section{References}

1. Fidelman B. Do pidsumkiv vydavnychoi roboty na Ukraini za 15 rokiv / B. Fidelman // Rad. knyhar. - 1932. - № 31. - S. 9-12.

2. Siropolko S. Istoriia osvity v Ukraini / S. Siropolko. - K. : Nauk. dumka, 2001. - $912 \mathrm{~s}$.

3. Isaievych la. D. Ukrainske knyhovydannia : vytoky, rozvytok, problemy / la. D. Isaievych. - Lviv : Instytut ukrainoznavstva im. I. Kryp'iakevycha NAN Ukrainy, 2002. $-520 \mathrm{~s}$.

4. Nyzovyi M. Ukrainska statystyka druku : osnovni etapy stanovlennia ta rozvytku / M. Nyzovyi. - K. : Kn. palata Ukrainy, 2002. - 96 s.

5. Yakovlev O. V. Istoryko-kulturolohichni vymiry knyzhkovoho druku v Ukraini u 20-ti roky KhKh stolittia : avtoref. dys. na zdobuttia nauk. stupenia kand. ist. nauk. 26.00.01 - teoriia ta istoriia kultury / O. V. Yakovlev. - K., 2010. - $16 \mathrm{~s}$.

6. Lototskyi O. Ukrainske drukovane slovo / O. Lototskyi // Antonovych D., Lototskyi O. Ukrainska knyha // Ukrainska kultura : lektsii za red. D. Antonovycha / upor. S. V. Ulianovska ; vst. st. I. M. Dziuba ; pered. slovo M. Antonovycha ; dodatky S. V. Ulianovskoi, V. I. Ulianovskoho. - K. : Lybid, 1993. - 592 s. («Pam’iatky istorychnoi dumky Ukrainy»). - S. 98-111.

7. Hodkevych M. Na porozi p'iatnadtsiatoho / M. Hodkevych // Rad. knyhar. 1931. - № 31. - S. 3-7.

8. O. B. Vydavnycha sprava na Ukraini / O.B. // Tryzub. -1926 . — № 45 (5 veresnia). - S. 16-20.

9. Kivshar T. Ukrainskyi knyzhkovyi rukh yak istorychne yavyshche (1917-1925 rr.) : monohrafiia / T. Kivshar. - K. : Lohos. 1996. - 334 s.

10. O sostojanii pechati na Ukraine (25 avgusta $1926 \mathrm{~g}$.) : Iz postanovlenija Politbjuro CK KP(b)U // Kniga i knizhnoe delo v Ukrainskoj SSR : sb. dokum. i materialov, 1917-1941 / [Sost. L. I. Gol'denberg (ruk. raboty) i dr.]. — K. : Nauk. dumka, 1985. - T. 1. - S. 159-164.

11. Istoriia Ukrainy / vidp. red. lu. Slyvka ; kerivnyk avt. kol. lu. Zaitsev. - Vyd. 3-tie, pererob. i dop. - Lviv : Svit, 2002. - 520 s.

12. Doroshenko V. Vydavnytstva / V. Doroshenko, P. Zlenko // Vydavnytstva i presa // Entsyklopediia ukrainoznavstva. Zahalna chastyna. Perevydannia $v$ Ukraini. - K. : NAN Ukrainy, In-t ukrainskoi arkheohrafii, 1993. - T. 3. S. 973-981.

13. Yakovlev O. Osnovni tendentsii rozvytku knyhovydannia v Ukraini $u$ 1924-1928 rr. / O. V. Yakovlev // Knyha v sotsiokulturnomu prostori (dosvid knyhovydannia KhIKh-KhKh st. i suchasni problemy) : dopovidi i povidomlennia Mizhnarodnoi naukovoi konferentsii, 3-5 travnia 1995 r. - Lviv, 1995. S. 56-57.

14. Ahuf M. Knyha - hvyntivka na kulturnomu fronti (Pidsumky vsesoiuznoi ta vseukrainskoi knyhotorhovelnykh narad) / M. Ahuf // Rad. knyhar. - 1929. № 1. - S. 2-6.

15. Pichuhyn M. Ukrainski vydavnytstva v 1928/29 rotsi (Za poperednimy danymy) / M. Pichuhyn // Rad. knyhar. - 1930. - № 3. - S. 3-4.

16. Shtoke H. Tekhnichna knyzhka do XIV richnytsi Zhovtnia / H. Shtoke // Rad. knyhar. - 1931. - № 31. - S. 7-9.

17. A. L. Asortyment masovoi ukrainskoi knyzhky / A. L. // Rad. knyhar. 1929. - № 1. - S. 6-8.

18. Fidelman B. Ukrainski knyzhkovi vydavnytstva v 1928/29 rotsi / B. Fidelman // Rad. knyhar. - 1930. - № 13 - 14. - S. 8-11.

19. Aleksandrov S. Pershi pidsumky knyzhkovoi produktsii USRR 1928/29 roku / S. Aleksandrov // Rad. knyhar. - 1930. - № 1. - S. 4-6.

\section{4}


20. Subtelnyi O. Ukraina : istoriia / per. z anhl. lu. I. Shevchuka ; vst. st. S. V. Kulchytskoho. - 3-tie vyd., pererob. i dop. - K. : Lybid, 1993. - 720 s.

В статье рассмотрены вопросы организации издательского дела в подсоветской Украине в междувоенный период после установления на этих землях власти российских большевиков и возникновения марионеточного создания УССР. Рассмотрено влияние политики украинизации на развитие украиноязычного книгоиздания и роль, которую отводили большевики издательскому делу в реализации своей политики.

Ключевые слова: издательское дело; издательства; издания; украинизация; украинское книгоиздание.

The issue of organization of publishing business in the Soviet Ukraine in the interwar period (after installing on these lands marionette Ukrainian Soviet Socialist Republic by the Russian Bolsheviks) is reviewed in the article. Influence of policy of the ukrainization on the development of Ukrainian-language publishing and the role in the implementation of this policy assigned publishing business by Bolsheviks are considered.

Keywords: publishing business; publishing house; edition; ukrainization; Ukrainian publishing.

Рецензент - В. Є. Слушаєнко, к.філософ.н., доцент, НТУУ «КПI»

Надійшла до редакції 03.04.15 